はプロムクレンールバープルが黃色から赤色に變色したことに起 因するののである。左右兩曲線の延長交點は $\mathrm{pH} 5.9$ 附近であつ た。

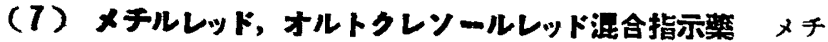
ルレ、ド溶液 $(0.02 \%) 0.5 \mathrm{cc}$ 及びオルトクレソールレッド溶液 (0.1\%) $0.2 \mathrm{cc}$ を加へ前同樣に滴定して第 4 圖 III 曲線を得た。 曲楾の左牛はメチルレッドが赤色から黄色に, 文右牛はオルトク レソールレッドか㣴色から赤色に禁色することに起因するのであ る。左右兩曲線の延長交點は $\mathrm{pH} 6.2$ であつた。

(8) ニュートラルレッド, フロムタレンールハープル混合指示 ニュートラルレ,ド溶夜 (0.1\%) 0.2 cc 及びブロムクレソー ルパーブル溶液 $(0.1 \%) 0.1 \mathrm{cc}$ を加へて前同樣に滴定して第 4 圖 IV 曲楾を得た。曲線の左牛はブロムっレソールが黄色から赩 に整色することに起因するすのである。左右兩曲線の延長交點は pH 5.8 であつた。

混合指示藥の種類によつては終點附近で滴定曲線が圆曲するも のああつたが(1)ニュートラルレッド，フェノールレッド及び(2)二ュ ートラルレッド, ブロムチモールブリウ混合指示菒の如きは斯か る現象も認められなかつた。斯くの如く適當なる 2 種の指示藥を 混合して光度滴定法によるならば中和滴定に際して N/100 或は 以下の如き稀薄標準液を使用しても極めて精度よく終點を決定す る事が出來た。

兩種指示藥の㵊合割合を變へる時は終點の $\mathrm{pH}$ は多少宛移動 し. 㢣色 $\mathrm{pH}$ の大なる方の指示䒚の添加量を暂す之終點は $\mathrm{pH}$
が小のオ゙へ移動した。

總括

(1) ニュートラルレッド, メチルレッド, ブロムクレソールハ ープル, フェノールレッド, アルファナフトールフタレイン, ブロ ムチモールブリウ, ブロムクレソールブリウ及びオルトクレソー ルレッド各指示藥を使用して光度滴定曲線を求め同時にアンチモ ン電極によつて被滴定溶液の $\mathrm{pH}$ を測定した。

(2) 光度滴定に使用し得る混合指示䒚ニュートラルレッド・フェ ノールレッド, ニュートラルレッド・ブロムチモールブリウ, $=_{ュ}$ トラルレッド・ブロムクレソールブリウ, ニュートラルレッド・アル ファナフトールフタレイン, メチルレッド・フェノールレッド, メチ ルレッド・ブロムクレソールバープル, メチルレッド・オルトクレ ソールレッド及びニュートラルレッド・ブロムクレッールパーブルの 滴定曲線を求めその急變點の $\mathrm{pH}$ を測定した。

（3）この滴定曲線は特徵ある曲線で混合指示藥の混合割合を 變へると少し宛急變點の $\mathrm{pH}$ は變化した。之によつて或範圍內 ならば任意の $\mathrm{pH}$ を終點とすることが出來た。

（4）中和光度滴定に混合指示薬を使用し，N/100 の如き稀薄 アルカリ標準液を以て滴定する場合でも極めて精度よく終點を求 むる事が出來た。

本研究を行ふれ賞つて終始御懇切に御指導下さつた 宗宮何行教 授に深謝する。

\title{
(56) ブテン，イソブテン混合ガスの分析に就て
}

\author{
芦野泉・玉山和夫
}

緒言

ズテンイップテン混合ガスを硫酸の選臎的吸收によつて分析す ろ方法に關しては Dobry: nski (Chem. Abst., 1926, 20, 1576)の 研究以来 Davis ( $J . A m$. Chem. Soc., 1930, 52, 721), Matuszak (Ind. Eng. Chem. Anal. Ed., 1938, 355)等により相次いで改良 され，硫酸吸收法自體種々なる短所を有するにも拘らず其操作の迅 速简便なる點から從來より廣く利用されて來た。近年インブテンを 原料とする諸反應の研究が盛になるに從て一定の接䚡條件を以て する硫酸吸收法の詳細なる检討並儿改良が度々試みられて居り(掬 山㙛，化學評論，昭和 15,6 月，68; 棸田勉，本誌，昭和 16,4 月, 313; 新宮春男, 同, 昭和 16,7 月, 548 ; 山岡篤史, 海燃研, 昭和 16，148)，此方面化常なる進步が見られるが操作の容易且 迅速性と云子㩆よりすれば未だ改良の涂地がある。且亦從來提唱さ れて居る力法の大部分はマッザーク法を除いては分析を終る每に 酸吸收生成物加吸收能を促進する誤差を避ける篇にその都度酸を 成来せねばならぬので多數且頻繁に分析を行ふ如き場合少からぬ 不便がおる。

著者等はフテン分析に虽り迅速に多数の分析を行子必要加ら操

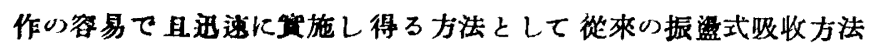

を改良しその大きな缺陷である再現性の不良を向上させる第飞一 定の接觸條件を機械的な何轉運動に求め, 又使用硫酸の取拔操作を 改良して後述の如き特殊ピペットを考案して簡單な圆表と共に使用 して居るが其結果は分析精度る 從來の方法に比し大なる差を認め ず特に再現性が甚だ良好であるので迅速を必要とする場合適切な るものと信じ此庭に報告する。

\section{装置及び操作法}

著者等の考案した裝置は第 1 圖の如きものである。郎ち容器部 分は吸收ピペっト $\mathrm{E}$ 改び充媜管 Fより成り恒溫槽及び恒溫槽內， に於て E を包轉せしめる包轉軸 $\mathrm{H}$ 及び小型電動機，滑車等の䮠 動裝置を附隨する。吸收ピべト $\mathrm{E}$ け充填管 Fを接續し得る容 量 $120 \mathrm{cc}$ の圓筒形單式ピベットで F を通じ $68 \%$ 硫酸を充填す， る。 A, C, D は各々二方活柾であり $\mathrm{E}$ はガス導入後佰溫槽內の 厄轉軸 Hにネジにて取附け四轉し得る。B は E 及び F の摺 合せ部分である。充填管 F の容量け $\mathrm{E}$ を充す文の量, 郎ち 120 cc より稍々多量であればよいが $130 \mathrm{cc}$ のbのを用ひて居る。G は酸量 $20 \mathrm{cc}$ の標線である。 $\mathrm{F}$ は操作中離脫され $\mathrm{E}$ は恒㴘槽中に ‘て電動機により包轉する。電動機け通常の小型交流電動機 $(1 / 20$ HP) を使用したが電唒調整機の怍用又は、小型の间期電動機を使用 


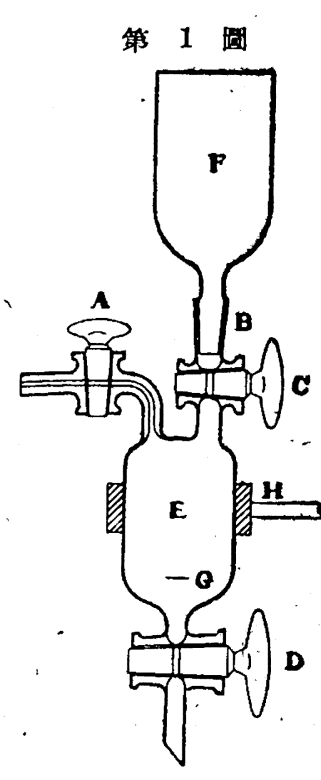

ナれば四轉の不齊に對する顧虑が少 w。

操作法 吸收ピペ・ E に F を接 着し $A ， \mathrm{C}$ を開き D を閉ぢ Fより $\mathrm{E}$ 中に酸を導入し $\mathrm{A}$ コックの位置迄 充填する。酸が $\mathrm{A}$ コックに達する時 A を閉ぢ Dを少し開いて C コックに 酸が達する迄加減し C, D を閉ぢる。 $\mathrm{C}$ コック上部及び $\mathrm{D}$ コックの外部に残 る少量の酸は廢酸受ビーカー (150 cc 程度) を D の下方に置き包轉して $\mathbf{C}$ コック上部の殘夜落し去り $\mathrm{F}$ を離脫 する。

全容量 $120 \mathrm{cc}$ に酸を充した $\mathrm{E} に$ $100 \mathrm{cc}$ ヘンベルビュレットを接䌅し水準 管を上部の定位置に置いて A を開き 試粼ガス $100 \mathrm{cc}$ を導入すると同時に $\mathrm{D}$ を開き酸を新酸受ビーカー（150cc 程度）に出し酸量が $\mathrm{G}$ 線 の示す $20 \mathrm{cc}$ の位置に來た時に $\mathrm{D}, \ddot{\mathrm{A}}$ を閉ぢビュレットを取外し E を恒溫槽內の包轉軸に取付電動機のスギッチと秒時計を同時に 始動し E の包轉を始める。100 cc のガスと $20 \mathrm{cc}$ の $68 \%$ 硫酸 はピヘ・ッ中に包轉し乍ら混和吸收される。包轉運動中はスト口 ボスコープを滑車に附し文は $\mathbf{E}$ の包轉を見乍ら抵抗器によつて $100 \mathrm{rev} / \mathrm{min}$ を保持する如く調篩する。

2 分間の包轉後電動機スキッチを切り包轉を止めて恒㴘槽より 取出し E， F を接續し F に硫酸 (使用濟の廢酸) を充してビミ レットを接縜し C，A を開く。水準管を下方定位置に置きビェレッ

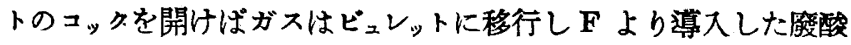

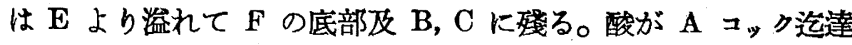
した時コっクを閉がガス容積を實取れば吸收減量となる。之に後 迅の補正を施してイソブテン量を算出する。猶分析の初めに使用 硫酸の溫度を恒溫槽溫度と同一ならしむる事が必要である。結局 1 四の分析に當つて實際使用される硫酸の量は $120 \mathrm{cc}$ 中の $20 \mathrm{cc}$ で垡餘の $100 \mathrm{cc}$ は新酸として再び使用し得る。

吸收條件 著者等の採用した吸收條件は次の如くである。

\begin{tabular}{ll|ll} 
硫酸婊度 & $68 \%$ (重量) & 回轉時間， & 2 分 \\
回 轉 數 & $100 \mathrm{rev} / \mathrm{min}$ & 恒溫槽溫度 & $18^{\circ} \mathrm{C}$
\end{tabular}

試料ガス 本分析に使用した試料イソブデンは武田化學製最純 イツブタノールを精溜し $108^{\circ} \mathrm{C}$ の溜分を活性アルミナゲル（國菲 工業製）により $400^{\circ} \mathrm{C}$ で脫水してイソブテンを探り，之を勝野正 治氏（本誌 昭和 $16,44,898$ )の行つた方法に從て $67 \%$ 硫酸水 溶液に吸收せしめて得たる第 3 級ブタノールを脱水苳酸にて脫水 してイソブテンを得CVanino, Präparati e, Chemie. Band II, 3 照) 之を $-20^{\circ} \mathrm{C} に て$ 液化し精製したものを試料としたが之 は臭素水によるオレフィン分析の結果 $99.3 \%$ を示した。

$n$ ブテンは武田化學製純ノルマルブタノールを精溜し $117^{\circ} \mathrm{C} の$ 留分を探り同樣に脫水して液化精製したものを $87 \%$ 硫酸により 3 包洗淡, 其都度 $68 \%$ 硫酸に一定條件下に吸收せしめた結果最 後の 3 包に於て同一吸收值を示したすのを試料 $n$ ブテンとし た。臭素水によるオレフィン分析結果は $99.0 \%$ であつた。

上記の $n$ ブテン及びィソブテンを夫々標準狀態に於て計量し た上兩者を配合してイソブテン含量 0〜70\%迄の配合ガスを各々
201 宛準備して試料に供した。

\section{覽の 部}

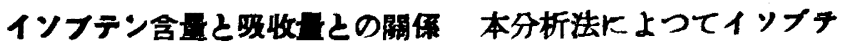
ン含量 0〜70\% を含むブテン湦合ガスを $15^{\circ} \mathrm{C}$ 及び $18^{\circ} \mathrm{C}, 761.2$ $\mathrm{mm}$ で分析した結果は第 2 喕の如くイソブテン 0 70\% のE己合 の範固內では實驗的にイソブテン含量と喃酸吸收量との閶係は值 線的關係と看做し得る。

第 2 圆 イソブテン含量と硫酸吸收量の罚保

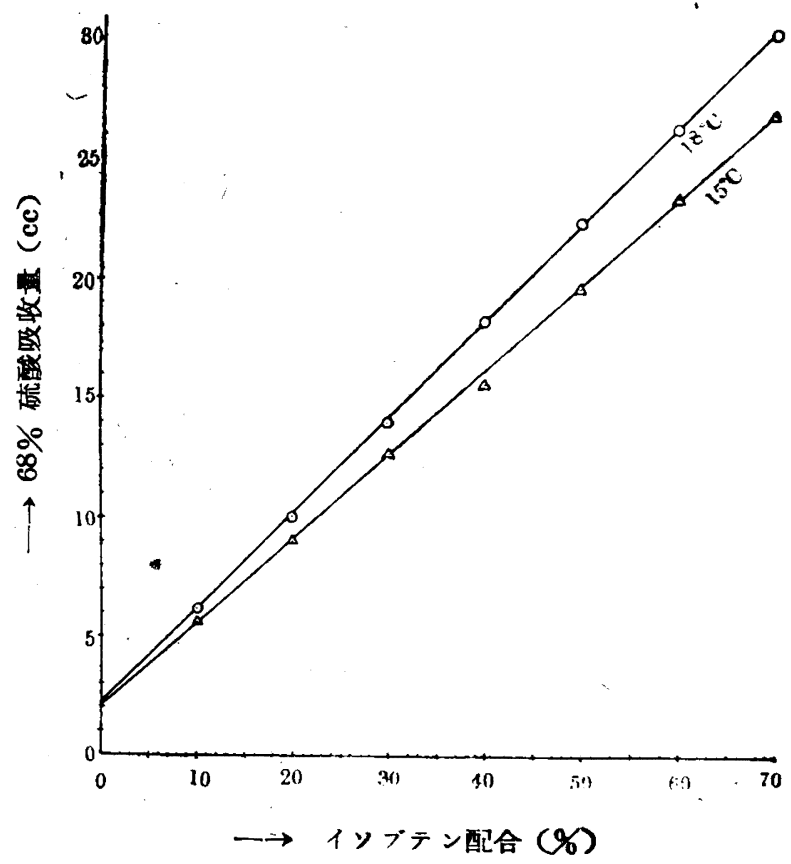

针算法 上記の實驗結果から $15^{\circ} \sim 18^{\circ} \mathrm{C}$, 包轉時間 2 分, 1 ソブテン含量 0〜70\%の範图に於てはイソブテン含量と硫酸吸收 量とは直線的關係と看做し得るから吸收量 $V_{a}$ とイソブテン含量 $V$ c との間には次の關係が成立する。

$$
\begin{aligned}
& V_{a}=a V_{c}+b \\
& V_{c}=\frac{V_{a}-b}{a}
\end{aligned}
$$

又 $V a$ は試料ガス中のブテンが他のガスによつて稀覙せられて 居る場合は過永值を示す。斯かる場合は景来水吸收を以てがス中 のブテン濃度を測定しその百分率を $V_{b}$ とし試料がス中のブテン 含量とすれば略々头の關係が成立する。

$$
\begin{aligned}
V_{c} & =\frac{\frac{V_{a}}{V_{b}} \times 100-b}{a} \times \frac{V_{b}}{100} \\
V_{c} & =\frac{V_{a}-\frac{b}{100} \cdot V_{b}}{a} \\
\therefore V_{c} & =\frac{V_{a}-B \cdot V_{b}}{a}
\end{aligned}
$$$$
V_{c}=\frac{V_{a}-\frac{b}{100} \cdot V_{b}}{a} . \quad \frac{b}{100} \text { をとなると }
$$

前記吸收攸件下に各配合試料に就て行つた算の䊅果 $a, B$ は 夫ネ次の如き值をとつた。

$\begin{array}{lll}15^{\circ} \mathrm{C} & a=0.351 & B=0.02 \\ 18^{\circ} \mathrm{C} & a=0.398 & B=0.021\end{array}$

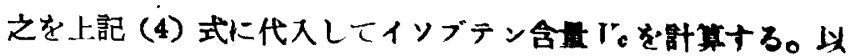
上を管際の数値に就て例示すれば夫の迾りである。 
奥素水吸收によるオレフィン含量 $68 \%$ 硫酸吸收诚量

测定溫。度

$V_{b}=96.2 \%$

$V_{a}=11.6 \mathrm{ce}$

$18^{\circ} \mathrm{C}$

$$
V_{c}=\frac{V_{a}-B \cdot V_{b}}{a}=\frac{11.6-0.021 \times 96.2}{0.393}=23.6 \%
$$

故に試料ガス中のイソブテンは $23.6 \%$ である。

回苦数に䣌て 四轉數の決定に當つてマッダ包轉計を使用して 回轉數の䋊化と吸收量の關係を二，三の配合試料に就て實驗した 結果第 3 圆の如く $100 \mathrm{rev} / \mathrm{min}$ 附近が可轉の不齊に.基づく誤差 が少いので $100 \mathrm{rev} / \mathrm{min} を$

第 3 圆包轉數と硫酸吸收量の關保

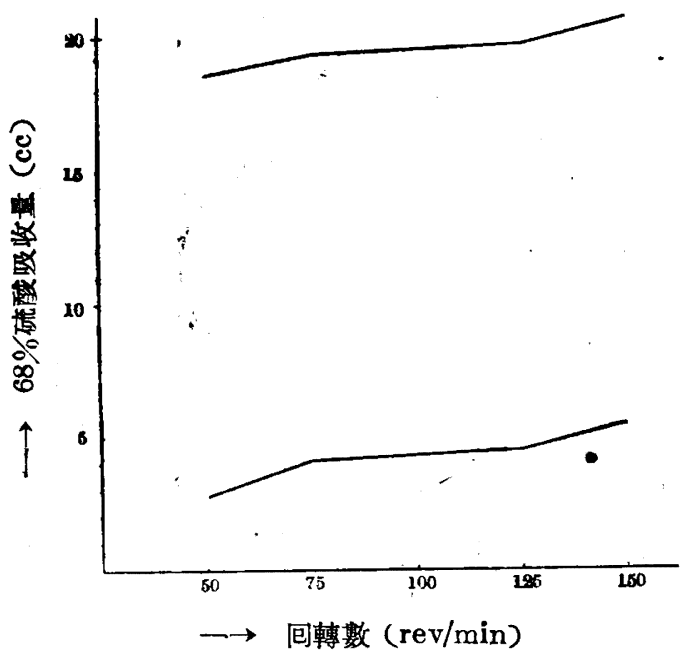

本分析法と他法との比較 本分析法による分析結果を他法によ るもの郎ち 1) 水素添加してポトビルニアク法により精溜分析せ
るもつ, 2) 監酸法 (Mc. Millan, Ind. Eng. Chem. Anal. Ed, 1937,9 , 511) 及び 3) 新㗬氏の提唱された改良マッザーク法(新 宮春男, 前出)による分析結果と比較すると第 1 表の如く其分析 精度は從來の提案せられた諸法に比して大なる差異を認めない。

第 1 表 各種分析法によるイソブテン分析結果の比較

\begin{tabular}{|c|c|c|c|c|}
\hline $\begin{array}{l}\text { 試料 } \\
\text { ガ }\end{array}$ & $\begin{array}{l}\text { 低 溫 } \\
\text { 分溜法 }\end{array}$ & $\begin{array}{l}\text { マッザ } \\
\text { ーク法 }\end{array}$ & 醞酸法 & 本分析法 \\
\hline I & $-\%$ & $8.4 \%$ & $7.8 \%$ & $7.6 \%$ \\
\hline II & 14 & 13.8 & 11.6 & 12.5 \\
\hline III & 26 & 27.8 & 27.3 & 27.5 \\
\hline IV & - & 48.6 & 47.5 & 48.2 \\
\hline
\end{tabular}

析結果の再現性に雄て 本分析法による分析結果の再現性は 甚だ良好であり試料ガス 2 四の分析に於ける吸收量の差は最大 $0.4 \mathrm{cc}$ であつて $15^{\circ} \mathrm{C}$ に於てはイソブテン含量の約 $1 \%$ に相當す ろ。この場合も分析を 3 四反復すれば殆ど同一皮收值を出寸事が 出來, 分析者の熟練の度は左して關俰しない。

總 括

1. ブテンイソブテン混合ガスの硫酸吸收による分析法を改良 し操作容易且迅速なる包轉振盪による分析裝置を考案し之により イソブテンの實際含量と $68 \%$ 硫酸による吸收量との關係を求め 計算式並に圖表を作製した。

2. 本法による分析結果を二:，三の分析法による結果と比較し てその精度を考察した。

附記 本研究の發表を許可せられた當往代表取締役渡邊四郎氏 並に御指導を賜つた研究所長江口孝博士に厚く感謝の意を表する。 猶本管驗に終始助力せられた尾張勉君に感謝する。

（東京帝國大學工學部工業分析化學研究室）（昭和 17 . 年 11 月 20 日受理）

(57) 粗製硫安中のピリヂン定量分析法に就て 宗.宮向行・神森大彥・松田龜松

緒言

石炭乾留の副生物たる粗製硫安の品位決定に際し粗製硫安中に ピリヂン若くはピリヂン塈が混在するときは此ピリデン性空素が アンモニアの窒素に加算され誤差の原因となつてるる。此誤差を除 くために粗製硫安中のピリヂン定量法を研究した。

硫安中のビリヂン定量法には比色法 (R.I. Alckseev. Zavodskaya. Lab, 19398. 807〜9, ) 及び滴定法が知られてるるが比較的 解單で精度かよいと思はれるのはハーベイ・スパークスの方法 (T. F. Harvey \& C. F. Sparks, J. Soc. Chem. Ind., 1918. 37, 41) である。著者等はこの方法を探用し工場に於てる使用出來る程度の 简便分析法とし, 同時にその基礎的研究を行つた。先づ简便分析法 を述へ，その基礎研先，分析例並に分析法に對する注意を記載す ๖.
（1）要 旨 試粼を食㿼水に溶解し硫酸々性となしたる後沃 素を加へて試料中の硫酸ピリヂンを沃化物として沈搌せしめ之を 濾過洗淡しチオ硫酸ソーダ溶液に溶解し標準苛性ソーダ溶液にて ピリデン監を滴定する。

（2）裝 置 沘激並に潜過裝置として容量 $300 \mathrm{cc}$ の分液漏斗 を用ひ，其コックの上方に脫脂綿をガラス棒（先端を圆錐狀に尖 らせたものが便利である）の先に詰め之を第 1 圖の如く吸引几得 る樣にせるものである。

（3）試 藥 沃素溶液の調製は沃素 $13 \mathrm{~g}$ 及び沃素カリ $13 \mathrm{~g}$ を水 $100 \mathrm{cc}$ に溶解する。

洗液の調製は $10 N$ 硫酸 $10 \mathrm{cc}$, 沃素溶液 $10 \mathrm{cc}$, 及び水 $190 \mathrm{cc}$ を混合する。

$N / 10$ 苛性ソーダ標準液の調製は苛性ソーダ $4.0 \mathrm{~g}$ を適量の水に 溶解し容量 $1 l$ のメスフラスコに移し水酸化バリウム飽和溶液約 $1 \mathrm{cc}$ を加へ，次に標線まで稀釋する。本規定液の力價は安息香酸 を以て检定する。 